\title{
Relationship between functional independence and grip strength in adult patients treated at intermediate care
}

\author{
Relação entre independência funcional e força de preensão manual em pacientes adultos \\ atendidos em cuidados intermediários
}

\begin{abstract}
Relación entre independencia funcional y fuerza de agarre en pacientes adultos tratados en cuidados intermedios
\end{abstract}

Lina Margarita Rentería-Sierra', Geraldine Hernández-Zorrilla², Esther Cecilia Wilches-Luna

\begin{abstract}
Patients that leave intensive care for intermediate care present compromised muscle strength and functionality. In this context, our main objective was to describe the correlation between functional independence and handgrip strength in adult patients at intermediate care unit (IMCU). This was an analytical, correlational, and prospective study that compared patients admitted to IMCU after a stay of more than 24 hours in intensive care, with invasive or non-invasive ventilatory support. We used Barthel index (BI) and hand dynamometry at admission/discharge from IMCU. In total, 69 patients were included, 62.3\% were men, with an average age of 63 years and a stay in intermediate care of five days. On admission to IMCU, 31.9\% had complete dependence and $66.7 \%$ severe dependence. The most compromised categories were "bathroom use" and "stairs". On the other hand, "dressing" was the one with the greatest improvement (admission 24.6\%, discharge $82.5 \%)$. A positive correlation $[(r=0.4)$ and $(p=0.000)]$ was identified between functionality and grip strength at admission and was maintained at discharge $[(r=0.6)$ and $(p=0.000)]$. We identified a positive correlation between $\mathrm{BI}$ scores and handgrip strength, remaining stronger at IMCU discharge.
\end{abstract}

Keywords | Muscle Weakness; Hand Strength; Activities of Daily Living; Patients.

RESUMO I Pacientes que recebem alta da Unidade de Terapia Intensiva (UTI) e passam para a Unidade de
Cuidados Intermediários (UCI) mostram comprometimento de funcionalidade e de força muscular. Nesse contexto, o objetivo foi descrever a relação entre independência funcional e a força de preensão manual em pacientes adultos na UCl. Este é um estudo analítico, correlacional e prospectivo em que são comparados pacientes admitidos em cuidados intermediários após permanência de mais de 24 horas em terapia intensiva, com suporte ventilatório invasivo ou não invasivo. O Índice de Barthel e a dinamometria manual foram utilizados na admissão e na alta do cuidado intermediario de 69 pacientes, 62,3\% homens (com idade média de 63 anos e permanência em cuidados intermediários por 5 dias). Na admissão ao cuidado intermediário, 31,9\% tinham dependência completa e 66,7\% dependência grave. As categorias mais comprometidas foram o uso do banheiro e das escadas. Vestir-se foi a atividade que apresentou maior melhora (admissão 24,6\%, alta 82,5\%). Na admissão, as mulheres apresentaram força de preensão manual de

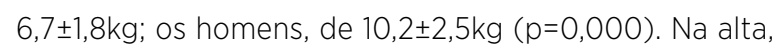
as mulheres apresentaram média de 12,3 $\pm 4,4 \mathrm{~kg}$; os homens, 19,3 $\pm 6,6 \mathrm{~kg}$ ( $p=0,000)$. Foi identificada uma relação positiva entre a funcionalidade e a força de preensão na admissão - $(r=0,4)$ e $(p=0,000)$-, mantida na alta - $(r=0,6)$ e $(p=0,000)$. A relação positiva entre funcionalidade e força de preensão destaca a importância dessas medidas para continuar a reabilitação pós-UTI. Descritores | Debilidade Muscular; Força da Mão; Atividades Cotidianas; Pacientes.

\footnotetext{
Universidad del Valle (Univalle) - Cali, Colombia. E-mail: lina.renteria@correounivalle.edu.co. Orcid: 0000-0003-2058-8262 2Universidad del Valle (Univalle) - Cali, Colombia. E-mail: geraldine.hernandez.zorrilla@correounivalle.edu.co. Orcid: 0000-0003-0632-4842 3Universidad del Valle - Cali, Colombia. E-mail: esther.wilches@correounivalle.edu.co. Orcid: 0000-0003-3255-7607
} 
RESUMEN I Los pacientes dados de alta de la Unidad de Cuidados Intensivos (UCI) y trasladados a la Unidad de Cuidados Intermedios (UCIM) presentan deterioro de la funcionalidad y la fuerza muscular. En este contexto, el objetivo de este estudio fue describir la relación entre independencia funcional y fuerza de agarre en pacientes adultos en UCIM. Este es un estudio analítico, correlacional y prospectivo, que compara pacientes ingresados en cuidados intermedios tras más de 24 horas en cuidados intensivos, con soporte ventilatorio invasivo o no invasivo. El índice de Barthel y la dinamometría manual se utilizaron en el ingreso y en el dado de alta de cuidados intermedios de 69 pacientes, el 62,3\% varones (con promedio de edad de 63 años y el tiempo de estancia en cuidados intermedios de 5 días). Al ingreso en cuidados intermedios, el 31,9\% estaban completamente dependientes, y el 66,7\% severamente dependientes. Las categorías más comprometidas fueron el uso del baño y las escaleras. La actividad que mostró una mayor mejora fue vestirse (un 24,6\% al ingresar, y un 82,5\% al dar de alta). Al ingreso, las mujeres tenían una fuerza de

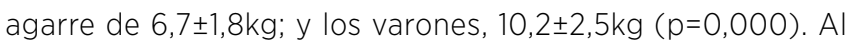
darles de alta, las mujeres tenían un promedio de fuerza de $12,3 \pm 4,4 \mathrm{~kg}$; y los varones, 19,3 $\pm 6,6 \mathrm{~kg}$ ( $p=0,000)$. Se identificó una relación positiva entre funcionalidad y fuerza de agarre al ingreso $(r=0,4)$ y $(p=0,000)$, mantenida al alta $(r=0,6)$ y $(p=0,000)$. La relación positiva entre la funcionalidad y la fuerza de agarre señala la importancia de esas medidas para continuar la rehabilitación pos-UCl.

Palabras clave | Debilidad Muscular; Fuerza de Agarre; Actividades Diarias; Pacientes

\section{INTRODUCTION}

Intermediate Care Units (IMCU) are responsible for the management of patients that require continuous monitoring, once they are no longer at critical risk ${ }^{1}$. Patients that survived a critical illness at the Intensive Care Unit (ICU) are sent to the IMCU, arriving there with health issues generated by prolonged rest and muscle weakness acquired in the ICU (ICUAW). This adds to the individual health condition, causing a decrease in their functional capacity and their muscle strength, which results in a cost increase due to prolonged hospital stay ${ }^{2,3}$. The consequences of ICUAW are functional dependence and neurocognitive disorders that make it difficult to perform activities of daily living (ADL), and can persist up to five years after hospital discharge $e^{4}$. Evidences emphasize the importance of assessing functional independence and muscle strength in critically ill patients ${ }^{2,4,5}$; however, studies evaluating the follow-up of these variables during stay in the IMCU are scarce. Identifying the weakness acquired at the ICU is not enough; patients must be monitored and rehabilitated during their stay at the IMCU, considering the alterations after hospital discharge that may compromise their quality of life $\mathrm{e}^{4,6,7}$. Therefore, we aimed at describing the correlation between functional independence and handgrip strength in adult patients in an IMCU and comparing the level of functionality upon admission and discharge.

\section{METHODS}

\section{Patients and setting}

We obtained an approval from the Human Ethics Committee of the Universidad del Valle with code 235-017. Subsequently, an alphanumeric identification code was assigned to the patients. An analytical study of correlational design with prospective temporality was conducted in an IMCU with 17 beds (March-June 2018). The sample size for finite populations was estimated with a $95 \%$ confidence, a $95 \%$ power, and a 0.20 estimated correlation obtained from a pilot test with 10 patients. Family members and patients signed informed consent prior to their participation in the study. Sixty-nine adult patients that met the inclusion criteria were selected for the study.

\section{Inclusion and exclusion criteria}

The inclusion criteria were patients older than 18 years, with at least 2 days of hospitalization in the ICU, who had invasive (IMV) or non-invasive mechanical ventilation (NIMV) for more than 24 hours. Patients that had or have had any of the following diseases: Sepsis, Acute Respiratory Distress Syndrome, Systemic Inflammatory Response, Multisystemic Organic Failure. We also included patients that had received glucocorticosteroids or neuromuscular blockers, and patients that had received parenteral nutrition. Exclusion criteria were patients 
with a BI greater than 75 points, with a stay in ICU of less than 24 hours, who presented physical, auditory, or cognitive alterations that prevented the development of the measurements, and who did not sign the informed consent. Isolated patients were also excluded. Figure 1 shows specifications of patients included and excluded.

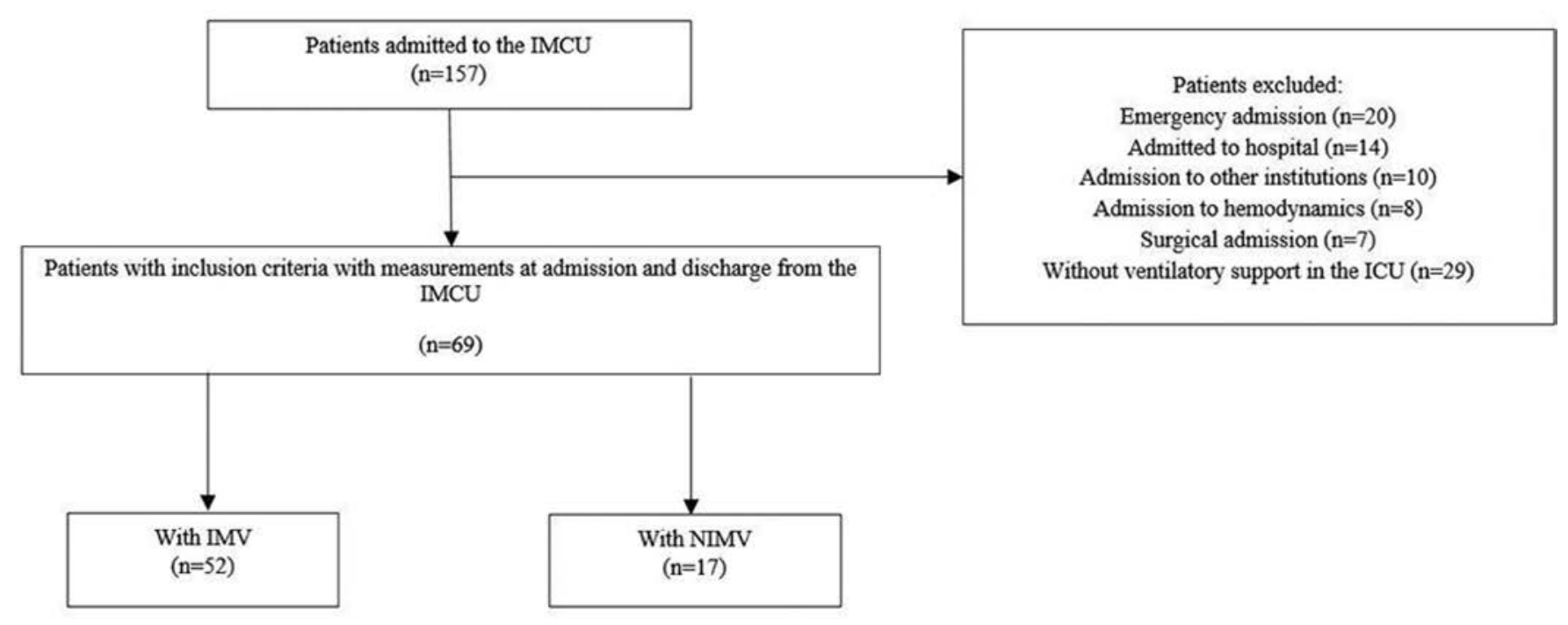

IMCU: Intermediate care unit; IMV: Invasive mechanical ventilation; NIMV Non-invasive mechanical ventilation.

Figure 1. Flow diagram of patients recruited and included in our study

\section{Measurements}

Handgrip strength and Barthel index (BI) were measured during the first 24 hours of admission and discharge from the IMCU. The BI was used to assess directly the degree of functional independence. BI gives an approximation of the dependence-independence level, depending on how the ADL is performed ${ }^{8-10}$, evaluating 10 activities: feeding, bathing, dressing, grooming, bowel control, bladder control, bathroom use, transfers, mobility, and stairs (climbing steps). These ADL are valued independently by giving a score of $0,5,10$ or 15 points to each activity. According to this scale, $0-20$ points reflects completely dependence; $21-60$ points severely dependence; $61-90$ points moderate dependence; $91-$ 99 points is slight dependence, and 100 points totally independence ${ }^{11,12}$. Handgrip force was measured with a pre-calibrated hand-held dynamometer (Smedley Digital Hand Dynamometer, Model: 12-0286), following the protocol of Ali et al. ${ }^{5}$. The patient was seated in an upright position, with shoulder adducted, elbow flexed at $90^{\circ}$, neutral wrist and feet supported. Patients grasped the instrument (dominant hand) as strongly as possible and hold it for six seconds. The highest value out of the three measurements was recorded. From the ICU clinical records, it was obtained data on age, gender, medical diagnosis, days of IMV or NIMV, length of ICU stay, severity score (Apache II), functionality seven days prior to admission to the ICU, and type of weaning from mechanical ventilation. In the IMCU, data was obtained from early mobility activities, physical therapy interventions and length of stay in the IMCU.

\section{Statistical analysis}

The information was recorded in a database in Excel version 2016 and the statistical analysis was conducted in the SPSS 25 program. For quantitative data, we used the measures of central tendency mean and median, and as measures of dispersion, the standard deviation (SD), interquartile range and coefficient of variation. An analysis of the distribution of the variables with the Shapiro-Wilks test was performed. For qualitative data, absolute and relative percentage, minimum and maximum frequencies were estimated. The significance level $\alpha$ used was 0.05 . For the comparative analysis of the quantitative variables, student $-t$ and the Levene test for normally distributed variables were used. For related samples, we used the Mann Whitney U test for independent samples and the Wilcoxon signed-rank test. Pearson correlation was used 
to estimate the correlation of the quantitative variables. Moreover, BI internal consistency was identified in the context of the IMCU, by the Cronbach's Alpha Index. All correlations between items were positive and significantly different from zero. The Cronbach's Alpha obtained for the 10 items was 0.74 (acceptable). Furthermore, to ensure the validity of the handgrip force measurement, intra and inter evaluator reliability was determined by the inter-class correlation index (ICC). Two physiotherapists performed three repeated dynamometry measurements in 20 healthy subjects. The classification of Landis and Koch was used for ICC interpretation ${ }^{13}$. The ICC for inter-evaluator reliability was 0.98 , indicating an almost perfect agreement. For intra-evaluator reliability, investigator \#1 obtained an ICC of 0.93 and investigator \#2 of 0.94 , indicating coherence.

\section{RESULTS}

Table 1 shows patients' sociodemographic and clinical characteristics. In total, $62.3 \%$ of the patients were men. The mean age was $63 \pm 17$ years.

Table 1. Sociodemographic and clinical characteristics of the sample

\begin{tabular}{|c|c|c|}
\hline & $\mathrm{n}$ & Frequency (\%) \\
\hline \multicolumn{3}{|l|}{ Age Range (Years) } \\
\hline $15-30$ & 5 & 7.2 \\
\hline $31-60$ & 26 & 37.7 \\
\hline$>60$ & 38 & 55.1 \\
\hline \multicolumn{3}{|l|}{ Gender } \\
\hline Male & 43 & 62.3 \\
\hline \multicolumn{3}{|l|}{ Medical Diagnosis } \\
\hline Cardiac surgery & 18 & 26.1 \\
\hline Sepsis & 12 & 17.4 \\
\hline Cardiac disease & 9 & 13.0 \\
\hline Neurosurgical & 7 & 10.1 \\
\hline Kidney disease & 5 & 7.2 \\
\hline Other & 5 & 7.2 \\
\hline Pneumonia & 4 & 5.8 \\
\hline Chronic obstructive pulmonary disease & 4 & 5.8 \\
\hline Trauma & 3 & 4.3 \\
\hline Abdominal surgery & 2 & 2.9 \\
\hline \multicolumn{3}{|l|}{ Invasive mechanical ventilation $(n=52)$} \\
\hline 24-48 hours & 36 & 52.2 \\
\hline$>48$ hours & 16 & 23.2 \\
\hline \multicolumn{3}{|l|}{ Non-invasive mechanical ventilation $(n=17)$} \\
\hline 24-48 hours & 8 & 11.6 \\
\hline$>48$ hours & 9 & 13 \\
\hline
\end{tabular}

\section{Level of functional independence}

Upon admission to the IMCU, 31.9\% of patients had complete dependence, and none of them had either a slight dependence or independence (Table 2). Moreover, $63.8 \%$ were severely dependent and none presented either a slight dependence or independence $(\mathrm{p}=0.000)$. When analyzing the BI categories during the stay in the IMCU (Table 3), bathroom use and climbing stairs were the most compromised activities, whereas getting dressed was the one with the greatest improvement [maximum score on admission (24.6\%) and discharge (82.5\%)]. Functional independence analyzed by gender showed that women had an average score of $29 \pm 15$. 4 points upon admission to the IMCU (severe dependence), and men presented $34.1 \pm 17.2$ points. At discharge, improvement was observed for both genders; however, men achieved a greater functionality recovery $(\mathrm{p}=0.005)$.

Table 2. Level of functional independence measured with the BI, at admission/discharge from the IMCU

\begin{tabular}{|c|c|c|c|c|}
\hline \multirow[b]{2}{*}{ Functionality level } & \multicolumn{2}{|c|}{ Admission IMCU } & \multicolumn{2}{|c|}{ Discharge IMCU } \\
\hline & $n$ & $\begin{array}{l}\text { Frequency } \\
(\%)\end{array}$ & $n$ & $\begin{array}{l}\text { Frequency } \\
(\%)\end{array}$ \\
\hline $\begin{array}{l}\text { Complete dependence } \\
\text { (0-20 points) }\end{array}$ & 22 & 31.9 & 4 & 5.8 \\
\hline $\begin{array}{l}\text { Severe dependence } \\
\text { (21-60 points) }\end{array}$ & 46 & 66.7 & 44 & 63.8 \\
\hline $\begin{array}{l}\text { Moderate dependence } \\
\text { (61-90 points) }\end{array}$ & 1 & 1.4 & 21 & 30.4 \\
\hline $\begin{array}{l}\text { Slight dependence } \\
\text { (91-99 points) }\end{array}$ & 0 & 0.0 & 0 & 0.0 \\
\hline $\begin{array}{l}\text { Independence } \\
\text { (100 points) }\end{array}$ & 0 & 0.0 & 0 & 0.0 \\
\hline
\end{tabular}

IMCU: Intermediate Care Unit; BI: Barthel Index $(p=0.000)$.

Table 3. Maximum score of the BI for each daily living activity at admission and discharge from the IMCU

\begin{tabular}{lccc}
\multicolumn{1}{c}{ Categories } & $\begin{array}{c}\text { Admission } \\
\text { to IMCU } \\
(\%)\end{array}$ & $\begin{array}{c}\text { Discharge } \\
\text { from IMCU } \\
(\%)\end{array}$ & $\begin{array}{c}\text { Difference } \\
\text { admission/ } \\
\text { discharge IMCU } \\
(\%)\end{array}$ \\
\hline Feeding (0-10) & 65.2 & 84.1 & 18.9 \\
Bathing (0-5) & 2.9 & 4.3 & 1.4 \\
Dressing (0-10) & 1.4 & 30.4 & 29.0 \\
Grooming (0-5) & 24.6 & 82.6 & 58.0 \\
Bowel control (0-10) & 68.1 & 92.8 & 24.7 \\
Bladder control (0-10) & 55.1 & 81.2 & 26.1 \\
Bathroom use (0-10) & 0.0 & 0.0 & 0.0 \\
Transfer (0-15) & 4.3 & 18.8 & 14.5 \\
Mobility (0-15) & 1.4 & 14.5 & 13.1 \\
Stairs (0-10) & 0.0 & 0.0 & 0.0
\end{tabular}

IMCU: Intermediate care unit; BI: Barthel index 
When the level of functional independence was analyzed by groups of patients that received ventilatory support, we found that the group that received IMV upon admission to the IMCU had an average BI score of $33.8 \pm 17.2$ points and those who received NIMV $27 \pm 13.8$ points $(p=0.15)$. At IMCU discharge, patients with IMV obtained an average BI score of $55.6 \pm 15.7$ points and those with NIMV a score of $52.6 \pm 14.8$ points. The average scores for these two groups showed no significant differences $(\mathrm{p}=0.42)$.

\section{Handgrip force with dynamometry}

The analysis of handgrip force during IMCU admission/discharge by gender (Table 4) showed improvement for both men and women. Upon admission to the IMCU, patients with IMV presented a median handgrip strength of $9.5 \pm 4.15 \mathrm{~kg}$ and patients with NIMV $9.8 \pm 3.3 \mathrm{~kg}(\mathrm{p}=0.65)$. Upon discharge from the IMCU, the group of patients with IMV showed a median handgrip strength of $14.6 \pm 9.7 \mathrm{~kg}$, whereas the group supported with NIMV presented a median of $16.3 \pm 12 \mathrm{~kg}(\mathrm{p}=0.5)$. There was a positive correlation between BI score and grip strength. Upon admission to the ICU, a statistically significant positive correlation $(r=0.4)$ was identified $(\mathrm{p}=0.000)$ between the BI score and handgrip strength, which remained a little stronger $(r=0.6)$ upon discharge from the ICU.

Table 4. Comparison of handgrip strength on admission/discharge from the IMCU according to gender

\begin{tabular}{lccccccc}
\multirow{2}{*}{ Gender } & \multicolumn{2}{c}{ Admission IMCU } & & \multicolumn{3}{c}{ Discharge IMCU } & \\
\cline { 2 - 3 } Female & 6.7 & 1.8 & & 12.3 & 4.4 & 0.000 \\
Male & 10.2 & 2.5 & & 19.3 & 6.6 & 0.000
\end{tabular}

IMCU: Intermediate care unit

\section{DISCUSSION}

In our study, we aimed at describing the correlation between functional independence and handgrip strength in adult patients in an IMCU, also comparing the level of functionality upon admission/discharge. Our results showed a positive correlation between BI score and handgrip strength and emphasize the importance of evaluating functional status and muscle strength to identify the deficiencies and enable the continuity of intervention, possibly reducing the post-ICU hospitalization effects on functional independence.
The study by Kancir and Korsgaard ${ }^{12}$ described functionality level using the BI in 73 patients upon discharge from the ICU to the IMCU and found that $63 \%$ were severely dependent, $25 \%$ moderately dependent and $10 \%$ slightly dependent. Their results are contrasting with those obtained in our study, in which no patients were identified with slight dependence upon admission to the IMCU. Kancir and Korsgaard ${ }^{12}$ considered that their results emphasize the importance of the early identification of deficiencies, and the beginning of both the intervention and the service provision that reduce hospitalization effects on the patient's functional independence and quality of life.

Our results regarding the categories of the $\mathrm{BI}$ score at discharge from the IMCU were similar to the reported by Wilches-Luna et al. ${ }^{14}$, who identified the same behavior in the same categories of our study, with a median of 0 points on admission to the IMCU, and 5 points on discharge from the IMCU. According to this author, the improvement in these activities could be explained by the context of the IMCU, where patients have a lower level of severity, are more awake and have less vascular access, facilitating transfers from bed to chair and mobility.

We considered important to perform the analysis with the IMV and NIMV subgroups, since these factors can compromise strength. Some authors have reported that the probability of suffering ICUAW is four times higher in women than in men, the reasons for this difference is unknown and a lower muscle mass may be a predisposing factor ${ }^{13}$. We observed an improvement in handgrip strength for both genders, surpassing the cut-off points reported by Ali et al. ${ }^{5}$; however, men achieved greater recovery. Only a few studies report this measurement in the context of the IMCU due to the difficulty in comparing it with previous studies. When handgrip strength was considered, regardless of gender, we observed improvements in both IMV and NIMV subgroups. We recognize that the sample size of patients with NIMV was lower than that of patients that received IMV, which did not allow us to obtain conclusive data and establish differences. However, the results showed a correlation between the use of IMV and NIMV, since the latter affected the handgrip strength score to a lesser extent. This could be related to the fact that patients with NIMV in the ICU have fewer barriers to functional mobility, which favors the maintenance of strength, postural control and muscle tone, facilitating the continuity of mobility activities at IMCU and, in turn, favoring the gain of strength and functional independence. Given the lack of studies reporting the 
use of this measurement in the context of the IMCU, we consider that this measurement should be adopted in the care practice in the IMCU to continue the evaluation and rehabilitation processes established in the ICU and favor the improvement of ICUAW in the IMCU ${ }^{5,15-17}$. The strengths of this study were the evaluation of inter and intra-evaluative reliability for the measurement of dynamometry, the internal consistency of the $\mathrm{BI}$ and the quality control on the processes of information collection and analysis. However, some limitations were identified such as conducting the study in a single institution, which may cause biases related to IMCU particularities.

\section{CONCLUSION}

According to our results, functional independence at discharge from the IMCU had an improvement in women and men; however, men achieved greater recovery of functionality. We also found a positive correlation between BI score and handgrip strength. This study increases the evidence on the importance and necessity of incorporating validated measurements, which guide and facilitate rehabilitation interventions, promoting better clinical and functional results. We recommend to conduct a multicenter research with a larger sample size, including patients with IMV and NIMV, to extrapolate findings. Likewise, we recommend conducting studies that analyze the effect of functional mobility and physical therapeutic interventions on muscle strength and functionality in the context of the IMCU.

\section{REFERENCES}

1. Plate JDJ, Leenen LPH, Houwert M, Hietbrink F. Utilisation of intermediate care units: a systematic review. Crit Care Res Pract. 2017;2017:8038460. doi: 10.1155/2017/8038460

2. Mondragón-Barrera MA. Condición física y capacidad funcional en el paciente críticamente enfermo: efectos de las modalidades cinéticas. Rev CES Med. 2013;27(1):53-66 [cited 2021 Mar 9]. Available from: http://www.scielo.org.co/pdf/cesm/v27n1/ v27nla06.pdf.

3. Parry SM, Berney S, Granger CL, Dunlop DL, Murphy L, El-Ansary $D$, et al. A new two-tier strength assessment approach to the diagnosis of weakness in intensive care: an observational study. Crit Care. 2015;19(1):52. doi: 10.1186/s13054-015-0780-5

4. Wieske L, Dettling-Ihnenfeldt DS, Verhamme C, Nollet F, van Schaik IN, Schultz MJ, et al. Impact of ICU-acquired weakness on post-ICU physical functioning: a follow-up study. Crit Care. 2015;19(1):196. doi: 10.1186/s13054-015-0937-2
5. Ali NA, O’Brien JMJ, Hoffmann SP, Phillips G, Garland A, Finley JCW, et al. Acquired weakness, handgrip strength, and mortality in critically ill patients. Am J Respir Crit Care Med. 2008;178(3):261-8. doi: 10.1164/rccm.200712-18290C

6. Chlan LL, Tracy MF, Guttormson J, Savik K. Peripheral muscle strength and correlates of muscle weakness in patients receiving mechanical ventilation. Am J Crit Care. 2015;24(6):e91-8. doi: 10.4037/ajcc2015277

7. Cottereau G, Dres M, Avenel A, Fichet J, Jacobs FM, Prat D, et al. Handgrip strength predicts difficult weaning but not extubation failure in mechanically ventilated subjects. Respir Care. 2015;60(8):1097-104. doi: 10.4187/respcare.03604

8. Barrero SCL, García AS, Ojeda MA. Índice de Barthel (IB): Un instrumento esencial para la evaluación funcional y la rehabilitación. Plast Rest Neurol. 2005;4(1-2):81-5 [cited 2021 Mar 3]. Available from: http://www.sld.cu/galerias/pdf/sitios/ rehabilitacion/indice_1.pdf

9. Cid-Ruzafa J, Damián-Moreno J. Valoracion de la discapacidad fisica: el Indice de Barthel. Rev Esp Salud Publica. 1997;71(2):12737 [cited 2021 Mar 9]. Available from: http://scielo.isciii.es/pdf/ resp/v71n2/barthel.pdf

10. van der Schaaf M, Dettling DS, Beelen A, Lucas C, Dongelmans DA, Nollet F. Poor functional status immediately after discharge from an intensive care unit. Disabil Rehabil. 2008;30(23):1812-8. doi: 10.1080/09638280701673559

11. Barbosa Murillo JAP, Rodríguez MNG, Hernández HVYM, Hernández HRA, Herrera MHA. Masa muscular, fuerza muscular y otros componentes de funcionalidad en adultos mayores institucionalizados de la Gran Caracas-Venezuela. Nutr Hosp. 2007;22(5):578-83 [cited 20219 Mar]. Available from: http:// scielo.isciii.es/pdf/nh/v22n5/original8.pdf

12. Kancir CB, Korsgaard PK. Activities of daily living (Barthel Index) at discharge from the intensive care unit. Crit Care. 2010;14(Suppl 1):P439. doi: 10.1186/cc8671

13. Landis JR, Koch GG. The measurement of observer agreement for categorical data. Biometrics. 1977;33(1):159-74. doi: $10.2307 / 2529310$

14. Wilches-Luna E, Méndez A, Clarice Gastaldi A. Independencia funcional en pacientes adultos al egreso de unidades de cuidado intensivo e intermedio. Rev Chil Med Intensiva. 2018;33(1):7-14 [cited 2021 Mar 9]. Available from: https://www.researchgate. net/publication/325953778_Independencia_funcional_en_ pacientes_adultos_al_egreso_de_unidades_de_cuidado_ intensivo_e_intermedio

15. Dietrich C, Cardoso JR, Vargas F, Sanchez EC, Dutra FH, Moreira C, et al. Capacidade funcional em idosos e idosos mais velhos após alta da unidade de terapia intensiva: coorte prospectiva. Rev Bras Ter Intensiva. 2017;29(3):293-302. doi: 10.5935/0103-507x.20170055

16. Mehrholz J, Thomas S, Burridge JH, Schmidt A, Scheffler B, Schellin $\mathrm{R}$, et al. Fitness and mobility training in patients with Intensive Care Unit-acquired muscle weakness (FITonICU): study protocol for a randomised controlled trial. Trials. 2016;17(1):559. doi: 10.1186/s13063-016-1687-4

17. Murakami FM, Yamaguti WP, Onoue MA, Mendes JM, Pedrosa RS, Maida ALV, et al. Evolução funcional de pacientes graves submetidos a um protocolo de reabilitação precoce. Rev Bras Ter Intensiva. 2015;27(2):161-9. doi: 10.5935/0103-507X.20150028 